\title{
A Systematic Review of the Relations between Industrial Design Education and Industry in Turkey through SWOT Analysis
}

\section{Onder Erkarslan}

Department of Industrial Design, Izmir Institute of Technology, Turkey

ABSTRACT This study aims to evaluate the strong and weak aspects of industrial product design (IPD) and industrial design (ID) education in Turkey in the context of their relations with Turkish industry. This study was conducted in four major phases. The study started with a SWOT analysis of the economy in Turkey and continued with an analysis of ID education using data on undergraduate and graduate education programmes, the number of faculty members, the number of graduates 
and the number of registered students. After identifying the profile of the industrial designer from the perspective of industry through online job advertisements, the correlation between the expectations of industry and the philosophy of ID and IPD education programmes in Turkey was analysed. The findings demonstrate that Turkey is behind other countries in terms of intellectual property rights, new products development and investment in new fields of business. Moreover, the share of resources allocated for research and development is insufficient. The education model of IPD and ID graduate programmes is inconsistent with the industry expectations. The expectations of the industry and the educational emphases of university programmes are extremely incompatible. The findings of this study will help to develop cooperation between industry and education programmes and will thus lead to better employment opportunities for graduates of IPD and ID programmes.

KEYWORDS: industrial product design, industrial design education, Turkish industry, university-industry collaboration

\section{Introduction}

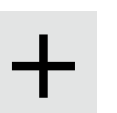

It is quite clear that industrial design (ID) initially emerged in developed countries. When it was imported by so-called developing countries, the development of ID followed a different path from that of developed countries as a result of economic, political and social differences (Bonsiepe, 1991). In spite of these differences, it is presumably acceptable to say that ID cannot be separated from the context of industrial development, both in developed and developing countries. From this standpoint, a discussion of ID in Turkey is of great interest, since the country has some characteristics that are relevant to ID development. Undoubtedly, the problem of the unrecognized role of the industrial designer in Turkey is associated with the fact that the development of Turkish industry was not concurrent with the development of the ID profession (Er et al, 2003; Er, 1993).

In developed countries, the profession of ID emerged and developed in line with the requirements of the industry; however, in Turkey, the industrial product design (IPD) profession did not emerge as a necessity but as a consequence of international interventions and compulsory steps taken for the sake of modernization. These international attempts were taken mostly with the initiative of US foreign policies in Turkey, as has been common in other developing 
countries. The new programme in the US for developing countries aimed to develop local handicrafts and small industries, and to explore the commercial potential of these products in internal and external markets - particularly the US market. The relationship between Turkey and the ICA (International Cooperation Administration, the forerunner of AID) started in 1955. During the same period, another international project with a UN initiative became influential in the development of ID in Turkey. This initiative was the establishment a new technical university in Ankara (known as METU - Middle East Technical University), which included the first ID programme in Turkey. Unfortunately, METU did not open until the 1970s, but beforehand, it inspired other universities as well as industry (Er et al, 2003). While IPD education in Turkey proceeds with a rational vision that benefits from technological and scientific developments, its difficulties with respect to the employment of design professionals by the industry continues to be an issue (Erkarslan et al, 2011).

Studies of IPD and ID education have focused on the contents of the curricula, the results derived through changes in the instructional methods and the comparison of the curricula between various universities. On the other hand, there are a few scientific studies that deal with the perception of ID practice in Turkey or the terms of employment of industrial designers by Turkish industry. Apart from the studies that convey personal experiences and estimations, there are a limited number of studies based on scientific data that examine their subject in light of surveys conducted with the managers of companies that employ designers or with the designers that are employed by those companies (Süel, 2006).

As argued in the published literature on design education, there seems to be a serious gap between the mission of ID programmes and the needs of the industry from a general perspective. Since design education seems reluctant to move beyond basic aesthetics and form-giving, the balance between theory and practice has become a crucial issue for curriculum development in the discipline (Kolko, 2004). The involvement of practice in design education also draws the borders between education and industry. Although the various applications of relations with industry in education (Boyarski, 1998; Çırpanlı and Er, 2006; Erkarslan, 1998, 2007, Erkarslan and Imamogulları, 2010; Erkarslan et al, 2011; Evyapan et al, 2005) have been widely discussed in the literature, many critical questions, such as whether design education should directly respond to the needs of industry, still remain as unanswered. Besides, policies and strategies in order to increase the intersections between education and industry is still a vital discussion in our field.

Design educators and professionals are always concerned with the issue of industrial designers' competencies. However, the quality of ID graduates is not generally regarded to be at the level expected by employers (Kaufmann, 1998), and there seems to be a gap between what students learn at school and what they are required 
to do in practice after graduation (Ball, 2002; Yeh, 2003; Yang et al, 2005).

\section{Method}

This study aims to evaluate the strengths and weaknesses of IPD and ID education in Turkey in the context of its relations with Turkish industry. There are four major phases in the study:

1. A SWOT analysis of economy in Turkey.

2. An analysis of ID education using data on undergraduate and graduate education programmes, the number of faculty members, the number of graduates and the number of registered students.

3. The identification of the profile of the industrial designer from the perspective of industry through online job advertisements.

4. A discussion of the correlation between the expectations of industry and the philosophy of ID and IPD education programmes in Turkey.

A descriptive research design was used in the phases of data collection and in the analysis of data to produce accurate descriptions and verifications as described in the seminal study by Wang (2008). Wang examined the job advertisements posted on four internet career sites in China and classified the qualifications expected of a prospective industrial designer. As a result of this research, Wang evaluated the findings of his classifications and recommended that IPD education should be diversified. Wang's study covered a broad range of subdisciplines under the general title of 'design', such as ID, mechanism design and interface design.

Although this study uses a methodological approach similar to Wang's with respect to the comparisons of job listing websites and education institutions, our method is original with respect to the integration of content analyses of curricula at selected universities in Turkey. This study considers only the keyword 'industrial designer' in the search of job listings, since the other design-related professions that Wang searched for in his study are unknown terms in Turkish industry and do not occur in the job listings.

This study aims to provide a framework for the perceptions of Turkish firms with regard to the ID profession. To uncover the reasons why companies recruit industrial designers, the companies' expectations of the industrial designer, and the perception of the ID professional in the sector, 54 out of 67 job advertisements posted on the following websites in September, October, November and December 2009 were included in the study: http://www.kariyer. net, http://www.yenibiris.com, http://www.monster.com.tr, http:// www.elemanonline.com, http://www.dexigner.com, http://www. etmk.gov.tr and http://www.iskur.gov.tr. We eliminated job advertisements that did not contain sufficient information. The number of job 
advertisements is small because the career websites removed those advertisements that were published prior to September, and the demand for industrial designers was low.

Once the necessary information was gathered, we compared the qualifications sought in the advertisements for an industrial designer on the career websites with the qualifications of the potential graduates from the IPD and ID departments. We also evaluated the curricula of the IPD and ID departments from ten universities with a four-year program of study that produced graduates during 2009. We considered the contents of the courses as specified by the departments on their websites. We then noted the differences and the similarities among the curricula and the courses.

For this reason, diploma titles offered by the universities are considered and only ten universities that offer Bachelor of Arts diplomas in ID were included from the original twenty-seven universities. These ten universities were the only institutions that had produced graduates by the year 2009, when this study was completed. The names of the universities included in the content analysis study are as follows, with the opening dates of their IPD and ID departments indicated in parentheses: Mimar Sinan Fine Arts University (MSGSU) (1971), Middle East Technical University (METU) (1979), Marmara University (MU) (1985), Istanbul Technical University (ITU) (1993), Yeditepe University (YU) (1996), Anadolu University (AU) (1999), Izmir University of Economics (IEU) (2004), Kadir Has University (KHU) (2005), Halic University (HU) (2005), Doğuş University (DU) (2005) and Izmir Institute of Technology (IZTECH) (1995).

The 16 universities eliminated from the study include Isık University, TOBB University, Meliksah University, Yasar University, Okan University, Erciyes University, Gebze Institute of Technology, Istanbul Trade University, Osmangazi University, Mersin University, Arel University, Suleyman Demirel University, Atılım University, Bahcesehir University, Gazi University and Izmir Institute of Technology. These universities either did not have undergraduate programmes or did not accept undergraduate students until after 2007 (Erkarslan, 2011).

While the qualifications described in the job advertisements differed with respect to terminology, verbal expressions and wording from those of the curricula and those described by the goals of the educational programmes, efforts were made to find commonalities that expressed the basic professional concepts that would allow us to compare the job requirements with the undergraduate university programmes. These common points were based on the three categories posited by Cooper and Press (1995) and categorized courses into concerns of 'design knowledge', 'concept skill' and 'contextual understanding'. These same three categories corresponded to the qualifications expressed in industry advertisements, although with slightly different terminology. We thus obtained a framework that allowed us to make useful comparisons between the institutions of education and industry. 
Because IPD and ID disciplines focus on practice and production, the importance of drawing and technical courses has increased. In this context, 'design knowledge' courses are those basic courses that involve the technical knowledge required to produce a project; the core subjects in the category of design knowledge include materials science, technical drawing and model making. In 'design skills' courses, students learn conceptual and technical information, but production is also practised. Students become familiar with several disciplines ranging from problem analysis to research and solution. The courses on 'conceptual understanding' aim to expand the conceptual world of the design student and to enhance students' knowledge and productivity in the field. Interdisciplinary courses such as design theories, marketing and history of design, which invoke new and different ideas within the scope of the projectmaking process for the design student, fall under this category. This classification by Cooper and Press provides an excellent foundation for this study, since it allows for the analysis and comparison of the curricula and job listings within a common format. For this reason, the authors listed the qualifications that appeared in the job advertisements and the contents of the courses in the curricula using the same categories (Erkarslan et al, 2011).

\section{Turkish Design Industry}

\section{The outlook of the design industry from a general profile of the Turkish economy}

Turkey experienced a simultaneously rapid recovery and dynamic period of growth following the drastic economic crisis of 2001. Today, Turkey is among the largest 20 economies of the world with a Gross National Product (GNP) of over US\$500 billion.

\section{Average age of the working population}

Turkey has a young population: 64 per cent of the population is below 34 years of age, and the age average of nation's working population is 28.5. With the highest population increase rate among the member nations of Organization for Economic Cooperation and Development (OECD), the population of the country increased from 73 million in the 2006 census to 77 million in the 2010 census. According to the Turkish Investment Support and Promotion Agency (TYDTA), owing to its active working population of over 24.7 million in 2007, Turkey is the only candidate country among the 27 member states of the European Union (EU) with such a large young workforce (TYDTA, 2010). According to data from the United Nations Statistics Department (UNSD), the percentage of Turks living in the city and towns is 67 per cent. This data indicates that the majority of the Turkish population has become urbanized. The average GDP per annum was 4.2 between 1998 and 2007. With this rate of growth, the Turkish economy ranks fifteenth among OECD states since 2008 (Elçi, 2010). 


\section{Export figures}

Exports from Turkey grew 11.3 per cent, with an increase of US\$113.686 billion in 2010, according to data obtained from the Turkish Exporters' Assembly (TiM). This figure is above the Turkish government's expectation of US\$111.7 billion. According to the figures of the TiM (Figure 1), the nation's total export figure, which was US\$11.6 billion in the same period of the previous year, almost doubled, increasing to US\$21.8 billion as of December 2010. The automotive industry is considered a leading industry in Turkey and ranks first in terms of industrial product exports with 14.83 per cent of total exports, followed by the ready-made clothing sector and textiles at 12.66 per cent and the iron-steel industry at 11.02 per cent (TiM, 2011). In the Turkish automotive market, the total market of automobile and light commercial vehicles amounted to 760,913 units from January to December 2010. Sales in automobile and light commercial vehicles saw an increase of 36.58 per cent over the previous 12 months, amounting to 557,126 in 2009. As of January-December 2010, Turkey's automotive exports amounted to US\$17,382,809,000 (TiM, 2011). Turkish exports were up 18.2 percent year-on-year in 2011 and rose to US\$134.6 billion. Turkey had its largest export earnings ever with nearly US\$135 billion in 2011 (TiM, 2011).

\section{Design industry}

Four major companies, namely, Oyak-Renault, Arçelik, Tofaş and Vestel, rank among the top 20 of the 500 largest companies in Turkey; their overall sales figures amount to TRY 10 billion. GrundigBeko and BSH Profilo rank among the top 50 companies. Eczacıbaşı construction materials, Kaleseramik, Otokar and Boytaşrank among the top 150 companies. Oyak Renault, Arçelik and Vestel Elektronik took their place among the companies with the highest export

\section{Figure 1}

Turkey's export figures (over the years in the period between 2002 and 2010 (TIM, 2011).

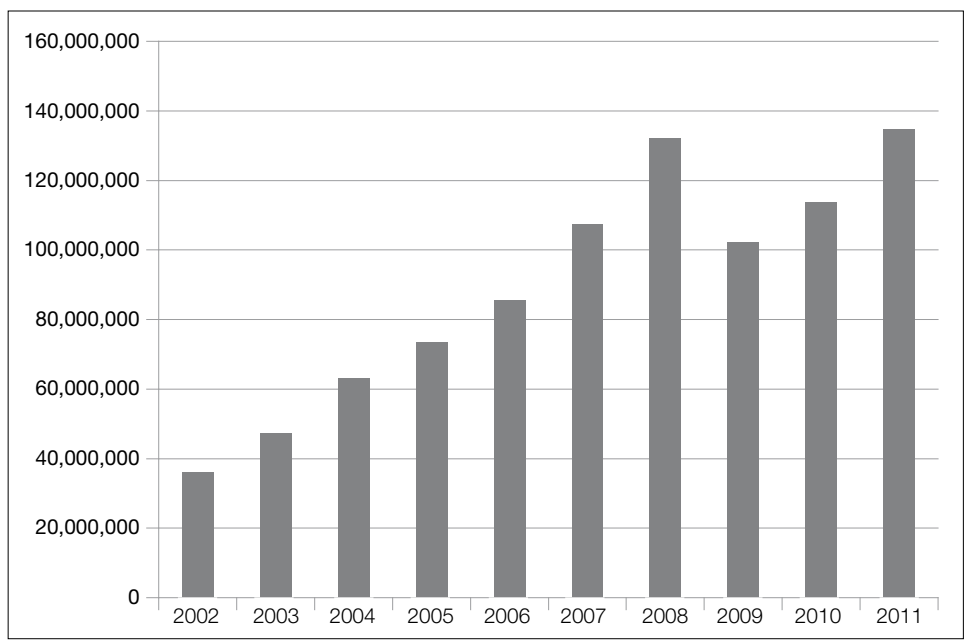


figures (Capital, 2007). Birsel+Seck and Ayşe Birsel, Murat Günak, Hasip Güler, Alev Ebuzziya, Aziz Sarıyer, Inci Mutlu and Defne Koz, who provide large international corporations such as Johnson and Johnson, Hasbro, Herman Miller, Hewlett Packard with design advisory services, are among the Turkish designers with a high profile. According to the latest information obtained from the Industrial Designers' Occupational Organization (ETMK), the total number of designers registered with such organizations is 350 (ETMK, 2010). Additionally, 899 graphic designers working in the design industry have registered with the Turkish Graphic Designers' Occupational Organization (GMK) (GMK, 2011).

\section{Creativity, innovativeness and intellectual rights in the design industry}

We need to bridge the gap in the field of innovativeness and creativity in order to further accelerate all of these positive developments. Deficiency in the field of innovativeness and creativity presents a large threat to the industry. The weakness of the nation in this field is quite obvious when compared with other nations (Figure 2). In addition, Turkey is behind other countries in terms of intellectual property rights, patents, new products, and development and investment in new fields of business, all of which can contribute to greatly economic growth. A noticeable increase was seen in the applications for design between 2008 and 2010 (Table 1).

We can observe that there has been an increase in design applications that are at the stage of evaluation in patent offices. Turkish, Polish and Chilean patent offices demonstrate similar patterns of applications that are at the evaluation stage. We are able to observe that the total number of patent applications in these nations is below the number of those applications that are at the evaluation stage

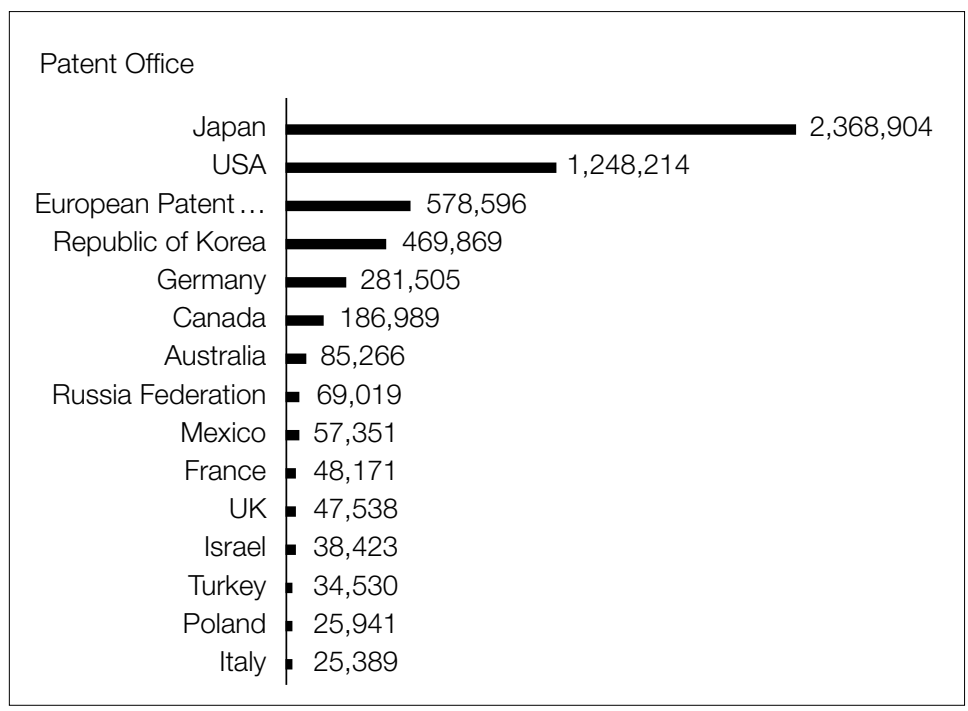

\section{Figure 2}

Patent applications at the evaluation stage (WIPO, 2010). 


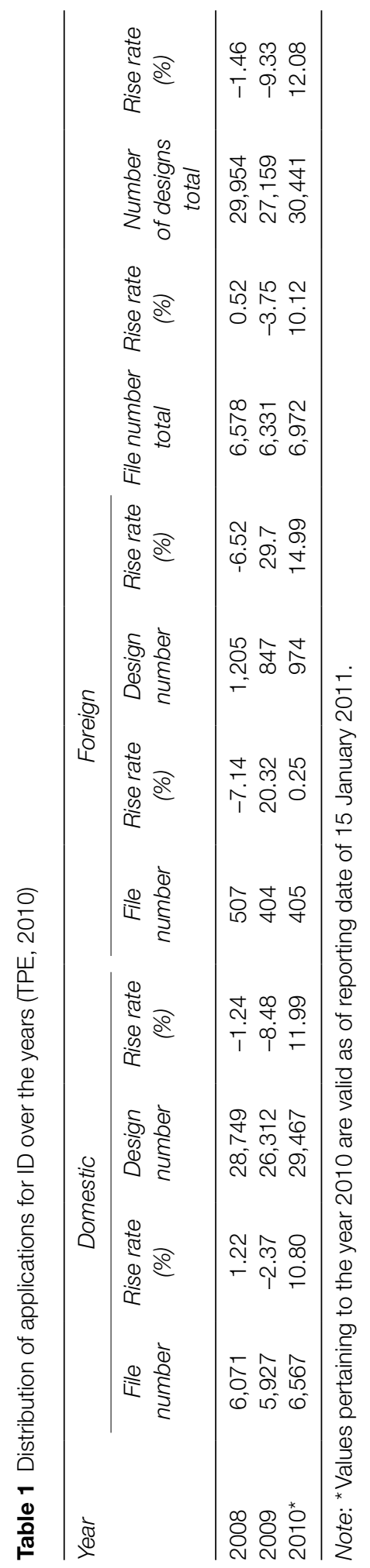


(Figure 2). According to the Turkish Patent Institute (TPE)'s 2008 data, the number of applications at the stage of evaluation $(34,350)$ is 14.4 times higher than the total patent applications $(2,397)$ (WIPO, 2010).

\section{Research and Development}

While Turkey is able to achieve high marks in terms of business and market efficiency, it has a low profile in terms of creativity capacity and business market efficiency in particular. In spite of the research and development (R\&D) agreement that became effective in February 2008, R\&D is still pursued by universities and research agencies that make use of national resources. The entrepreneurship industry in Turkey is below the OECD average with its share of 37 per cent. The rate is 62.5 per cent for the OECD as a whole. Such a rate difference indicates how small the share allocated for R\&D by the entrepreneurship industry is. Although the government takes precautions to increase the level of cooperation between the entrepreneurship and research industries, progress in this field is significantly below expectations (World Bank, 2009). Increased competition in the industry has increased awareness of companies and has motivated them to take part in education projects as sponsors. Aside from large-scale industrial enterprises, small- and mediumscaled enterprises (SMEs) will have to attach more importance to their R\&D activities given this increased competition. SMEs have started to understand the importance of developing products based on innovation instead of pirating.

\section{Support for sustainable design concepts}

The Turkish Design Advisory Board was established pursuant to the decree of the Council of Ministers as published in the Official Gazette dated 3 October 2009 (no. 27338) in order to accelerate the Turkish design industry. The Council was established to pass resolutions in the form of recommendations in order to identify design strategies and policies to increase the competitive power of Turkey in the international arena, to build and apply an implementation infrastructure, to give rise to designs with high added-value, to render Turkish designers and Turkish designs preferable in the world market, to assure cooperation between designers and industrialists and to build an image for Turkish designers. This institution was given legal status in Decree Number 2009/15355 (Official Gazette, 2009). The Turkish Design Advisory Council should support innovativeness and creativity within competitive market mechanisms, ensure that industry adopts sustainable design concepts and help industry to use advanced production technologies. Sustainable design requires us to consider product/service relationships as well as common features, such as reproduction, reuse, heat and energy, solid waste, cost reduction and recycling. 


\section{Unemployment rates and the employment of graduates of IPD and ID}

Unemployment, one of the weakest aspects of Turkish industry, affects the employment of IPD graduates negatively. Research conducted by Turkish Statistical Institute (TÜiK) on education status and unemployment data related to graduation fields confirms this reality. With regard to unemployment rates, graduates of computer departments rank first with 21 per cent, manufacturing and processing graduates are second with 20.2 per cent and graduates of art are third with 16.5 per cent. According to 2010 data, 14.5 per cent of all graduates of journalism and information, 15.1 per cent of business and administration graduates, 14.7 per cent of life sciences graduates and 16 per cent of social services graduates are unemployed (TÜIK, 2010).

According to the World Bank's data on the unemployment rates of women and men, the percentage of men employed in Turkey is 68 per cent while the percentage for women is 23.8 per cent. This percentage is far below the standards of the EU and continues to drop. After a drop in the unemployment rate by 10.3 per cent in 2007 , the unemployment rate increased to 11 per cent in 2008 and skyrocketed to 16-17 per cent in the first half of 2009. Unemployment rates for young people, people who live in urban areas and women are 20.5 per cent, 15.4 per cent and 10.2 per cent, respectively. Unemployment is more widespread in urban areas compared with rural areas, although the unemployment rate in rural areas is not known for sure (World Bank, 2009). According to statistics from the Turkish Employment Agency (ISKUR), it is clear that the unemployment rate for women is increasing (Table 2).

The Household Workforce Statistics of TÜiK covering May, June and July contain important data related to unemployment. Although

Table 2 Basic indicators (ISKUR, 2011)

Basic indicators, March 2010-11

\begin{tabular}{|c|c|c|c|c|c|c|c|}
\hline & \multicolumn{3}{|c|}{ March 2010} & \multicolumn{3}{|c|}{ March 2011} & \multirow{2}{*}{$\begin{array}{c}\begin{array}{c}\text { Rate of } \\
\text { change }\end{array} \\
\text { (\%) }\end{array}$} \\
\hline & Male & Female & Total & Male & Female & Total & \\
\hline Application & 73,433 & 43,087 & 116,520 & 70,814 & 40,205 & 111,019 & -4.72 \\
\hline The unemployed & 67,114 & 40,313 & 107,427 & 61,993 & 36,597 & 98,590 & -8.23 \\
\hline Other & 6,319 & 2,774 & 9,093 & 8,821 & 3,608 & 12,429 & 36.69 \\
\hline $\begin{array}{l}\text { Registered } \\
\text { workforce }\end{array}$ & $1,370,973$ & 552,866 & $1,923,839$ & 815,952 & 332,642 & $1,148,594$ & -40.30 \\
\hline $\begin{array}{l}\text { Unregistered } \\
\text { workforce }\end{array}$ & $1,227,701$ & 514,642 & $1,742,343$ & 669,931 & 293,022 & 962,953 & -44.73 \\
\hline
\end{tabular}


the annual rate of unemployment dropped by 2.5 per cent in July 2010 to 10.5 per cent, in December 2009, the rate increased to 12.2 per cent (TüiK, 2010). In 2009, the non-agricultural unemployment rate was 13.4 per cent. According to data from the World Bank in 2009, the unemployment rate was 19.1 per cent among the young population (World Bank, 2009).

\section{Lack of statistical data for design education and industry}

Although a high rate of unemployment fails to describe exactly why designers employed in the industry are affected, we do not have any other reliable data related to unemployed female and male industrial designers. In this context, the Turkish Design Advisory Council (TTDK) should keep reliable data as to ID education and industry and should publish such data periodically in the form of a report, as the UK Design Council did (2007, 2010).

For the time being, the number of female and male designers employed in the national design industry, the business fields in which they are employed, the number of designers working at home offices, the number of freelance designers, the number of unemployed designers, those employed abroad, those providing design advisory services, the number of designers who started their own businesses and the rate of employment for people from the design discipline and the other fields in such offices, the number of companies working in communication, multimedia, product and industrial design, interior design and the number of designers working at such companies should be statistically maintained. Reliable statistical data for ID education and the design industry in general is simply too scarce.

\section{ID Education}

\section{General status of IPD and ID undergraduate and graduate education}

Nineteen universities, seven state and twelve private, have IPD and ID departments (18 April 2011). Of these universities, seven departments are situated within an architecture faculty, two departments are situated within a faculty of engineering-architecture, six departments are situated within a faculty of fine arts, two departments are situated within a design and arts faculty, one department is within a faculty of fine arts-design and architecture and one department is within an industrial arts academy.

\section{The number of students studying in IPD and ID departments}

Statistical information related to education used in this stage of our research mostly covers the period between 2008 and 2010 (Table 3). The number of design students at Turkish universities between 2008 and 2010 was above 8,000, including, among these, 900 graduate students (YÖK, 2011). 


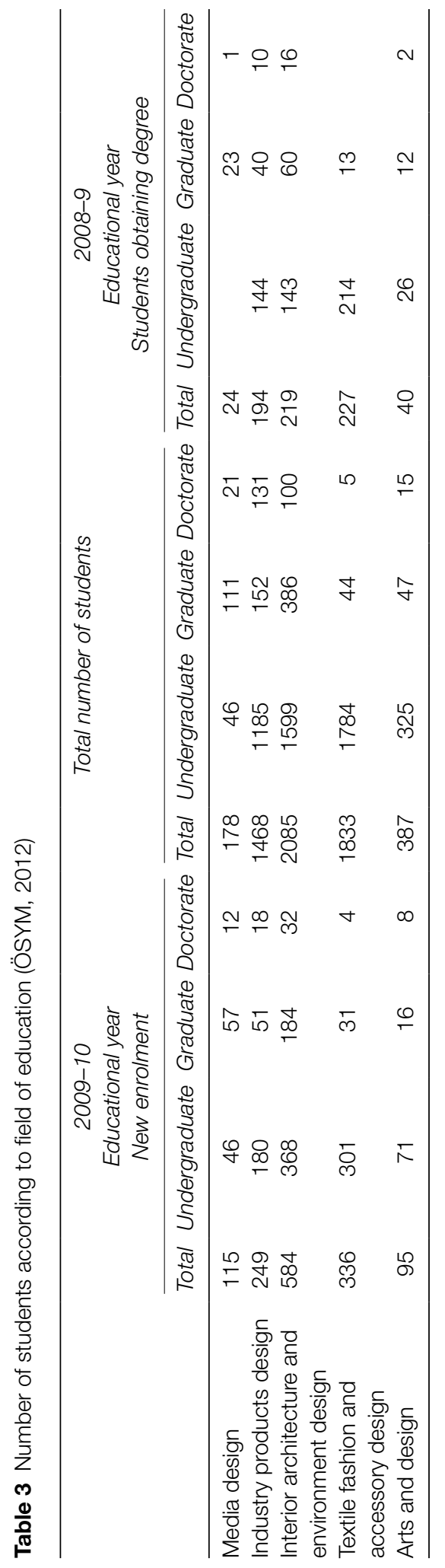




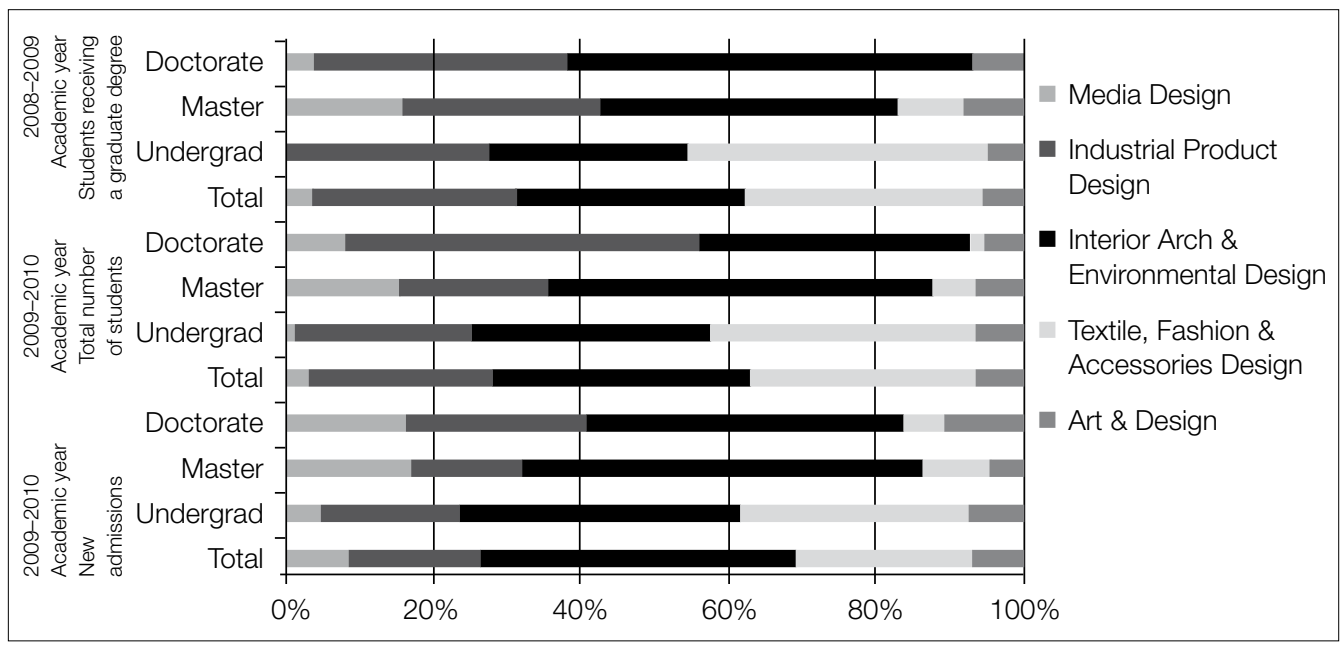

Figure 3 obviously shows that, during the academic year of 200910, media design (communication, digital and multimedia), interior architecture and environment design increased in popularity.

As indicated in the World Bank report that confirms such cases, there is an apparent growth in the Turkish design industry owing to the number of designers employed in the media design industry in Istanbul (World Bank, 2010). One reason for the popularity of media design is the fact that media is the fastest-growing industry. According to the report 'Overview to Global Entertainment and Media 2010-2014' prepared by PriceWaterhouseCoopers (PwC), an international auditing and tax consultancy company, in Turkey, the entertainment and media industry finished 2010 with US $\$ 5.862$ billion, an increase of 11.3 per cent over 2009 . The media industry is estimated to reach US\$9.7 billion by the year 2014 with a growth of 13 per cent on average within five years (PriceWaterhouseCoopers, 2010).

Table 4 shows that the total number of IPD students graduating from graduate and undergraduate programmes at nine top-notch universities in Turkey in 2010 was 1,664, including among these 350 graduate students.

\section{Interdisciplinary education policy}

The interdisciplinary education policy that comprises a strong aspect of IPD and ID graduate programmes and the flexible education schedule of such programmes enables students to be trained as designers who are able to synthesize different information and skills in a way that will make them work at joint projects efficiently (Table 5). The use of information and skills borrowed from different disciplines, a prerequisite of innovativeness and creativity, has increased the quality of design education and has positively increased the student profile of these programmes.

\section{Figure 3}

Percentage of graduate and undergraduate students according to their fields. 
Table 4 Total number of IPD students graduating from graduate and undergraduate programmes (2010)

\begin{tabular}{lccc}
\hline University & Female & Male & Subtotal \\
Undergraduate & & & \\
\hline AU & 175 & 98 & 273 \\
DU & 16 & 21 & 37 \\
HU & 26 & 42 & 68 \\
ITU & 232 & 175 & 407 \\
IEU & 46 & 38 & 84 \\
METU & 436 & 400 & 836 \\
MSGSU & 0 & $\circ$ & $\circ$ \\
& & & \\
Graduate & 5 & 4 & 9 \\
AU & - & - & - \\
DU & 82 & 72 & 154 \\
ITU & 28 & 20 & 48 \\
IZTECH & 58 & 31 & 89 \\
METU & & & 50 \\
MGSU & 903 & 761 & 1664 \\
Total & &
\end{tabular}

Source: Statistical information has been obtained from the registration offices of the respective departments.

Notes: $-=$ Not available; ${ }^{\circ}=$ number of MSGSU undergraduate graduates is not available; number of registered students is 189 for academic years 2010-11.

Table 5 Accepted disciplines for master's degree programmes in ID (Erkarslan and Imamogulları, 2010)

\begin{tabular}{ll}
\hline University & \multicolumn{1}{c}{ Fields accepted } \\
\hline MSGSU & $\begin{array}{l}\text { Disciplines identified according to respective year's } \\
\text { requirements and vision }\end{array}$ \\
MU & Architecture, Mechanical Engineering, Fine Arts \\
ITU & Engineering, Architecture, Fine Arts, Social Sciences \\
IZTECH & Ceramics, Architecture, Mechanical Engineering, City Planning \\
METU & $\begin{array}{l}\text { Architecture, Interior Architecture, Graphic, Mechanical } \\
\text { Engineering, Electronic Engineering }\end{array}$ \\
AU & $\begin{array}{l}\text { All disciplines (Statistics, Business Administration, Mechanical } \\
\text { Engineering, Cinema, Mathematics) }\end{array}$ \\
IEU & $\begin{array}{l}\text { Business Administration, Architecture, Interior Architecture, } \\
\text { Mechanical Engineering, City Planning, Textile Design, Fashion }\end{array}$ \\
& Design
\end{tabular}




\section{Formation of information and communication networks among IPD and ID departments}

Easy access to international publications, the increase in the database and publication diversity of university libraries, the rise in communication between IPD departments with IPD departments abroad and the exchange of students, lecturers and administrative personnel have enabled design students to gain experience in different cultures and countries.

\section{Process of university-industry cooperation}

The Turkish Scientific and Technological Research Agency (TÜBITAK) Science Board adopted implementation principles at its meeting of 9 July 1996 and began the University-Industry Joint Research Centres Program (ÜSAMP). The foundation of ÜSAMP has greatly contributed to state, industry and university cooperation, something lacking in Turkey prior to the present moment, and ensured that important centres would be established between university and industry during the period between 1996 and 2006 (TÜBITAK, 2003). At the moment, cooperation between IPD and ID departments and industry is far from what is desired. Global competition will require the design industry to come up with more innovative, environmentally friendly products with added value in the upcoming years. The global competition threat toward the Turkish design industry renders a communication network compulsory in the fields of education and practice that can effectively link university and industry. The lack of innovative education based on industry is a problem that needs to be overcome. Projects conducted within the framework of university and industry cooperation generally fail to come into being, leaving prospective applicants no opportunities. The rate of creation of state-of-the-art technology products was quite low in the joint studies conducted by the companies and academic researchers within the technology parks that enable cooperation between industry and universities (Kiper, 2010). Syllabuses should be periodically renewed in line with the expectations of industry; the renewal frequency of syllabuses, as shown in Table 6, is far from approaching the expectations of industry.

Table 6 Renewal frequency of graduate syllabuses according to university (Erkarslan and Imamogulları, 2010)

\begin{tabular}{ll}
\hline University & \multicolumn{1}{c}{ Frequency of syllabus renewal } \\
\hline MSGSU & Every semester \\
MU & Twice a year \\
ITU & Every ten years (last renewal 2002) \\
IZTECH & Renewed syllabus became effective in autumn 2009 \\
METU & Once a year \\
AU & Every three years \\
IEU & Once a year \\
\hline
\end{tabular}




\section{Lack of specialization in IPD and ID graduate programmes}

Having examined the education plans of IPD departments within fine arts, architecture, engineering, art, industrial arts academies and design faculties in Turkey (except for the interactive design programme at METU), we can see that all departments aim to train general designers. IPD and ID graduate programmes remain far from an orientation toward an education model based on specialization. IPD and ID departments quickly need to develop specialization programmes such as those oriented toward sustainable design, service design and strategic design.

The philosophical, obligatory, elective courses and the number of classes in IPD and ID departments within vocational academies and the fine arts, architecture and design faculties of seven universities are shown in Table 7.

\section{Number of permanent lecturers in IPD and ID departments}

There is a lack of permanent lecturers in IPD and ID departments. Table 8 summarizes the current status of employment in the field. The total number of academic staff in the IPD departments of 19 universities is below the number of academic staff of the ITU architecture department alone.

The number of professors in the ITU architecture faculty is nine times higher than number of professors in the IPD and ID departments of 19 universities. Likewise, the number of associate professors is two times higher. The total number of academic staff of the IPD departments at 19 universities is not enough to form a department when considering the number of necessary permanent staff. The scarcity of professors and associate professors causes the disciplines of IPD and ID to be underrepresented in the decisionmaking processes in university senates and on YÖK boards.

\section{Distribution of obligatory and elective courses in IPD and ID undergraduate education}

According to Cooper and Press's (1995) sorting method, courses contained in undergraduate education were divided into design theory (with a focus on the ability to develop design solutions, access to information, R\&D and the possession of qualifications that could help these to be developed in two and three dimensions such as computer-aided design and production, drawing, sketch techniques and the development of creative problem solution techniques), design knowledge (material information, production methods, modelling) and contextual understanding (history of design, design theory, marketing). Their distribution percentages are listed in Figure 4.

Upon examining Figure 4 in terms of the importance attached by ten universities to the course categories of IPD and ID departments and their field of specialization, it can be observed that the 
Table 7 Comparative analysis of graduate syllabuses at different universities

\begin{tabular}{|c|c|c|c|c|c|c|c|c|}
\hline \multirow[t]{2}{*}{ University } & \multirow{2}{*}{$\begin{array}{l}\text { Education philosophy of } \\
\text { syllabus }\end{array}$} & \multirow{2}{*}{$\begin{array}{l}\text { Condition for } \\
\text { graduation }\end{array}$} & \multicolumn{3}{|c|}{ Obligatory courses } & \multicolumn{3}{|c|}{ Elective courses } \\
\hline & & & $\begin{array}{c}\text { Number of } \\
\text { credits }\end{array}$ & $T$ & $P$ & $\begin{array}{c}\text { Number of } \\
\text { credits }\end{array}$ & $T$ & $P$ \\
\hline MSGSU & $\begin{array}{l}\text { Focuses on man-product } \\
\text { relationship, production, } \\
\text { industry and society-based } \\
\text { design research and } \\
\text { education }\end{array}$ & $\begin{array}{l}10 \text { Classes/ } \\
21 \text { credits }\end{array}$ & 4 Credits & & $\checkmark$ & 17 Credits & $\checkmark$ & \\
\hline $\mathrm{MU}$ & $\begin{array}{l}\text { Combines applied aspects } \\
\text { of design discipline with } \\
\text { theoretical education and } \\
\text { techniques that care for art }\end{array}$ & $\begin{array}{l}12 \text { Classes/ } \\
28 \text { credits }\end{array}$ & $\begin{array}{l}8 \text { Credits } \\
8 \text { Credits }\end{array}$ & $\begin{array}{l}\checkmark \\
\checkmark\end{array}$ & $\checkmark$ & 12 Credits & $\checkmark$ & \\
\hline ITU & $\begin{array}{l}\text { Presents an applied and } \\
\text { institutional education } \\
\text { structure that will conduct } \\
\text { necessary researches for } \\
\text { comprehensive design } \\
\text { problems }\end{array}$ & $\begin{array}{l}8 \text { Classes/ } \\
24 \text { credits }\end{array}$ & 12 Credits & $\checkmark$ & & 12 Credits & $\checkmark$ & \\
\hline IZTECH & $\begin{array}{l}\text { Program that presents } \\
\text { interdisciplinary education } \\
\text { and application in } \\
\text { technology and creativity } \\
\text { fields has a structure that } \\
\text { combines institutional and } \\
\text { application aspects in } \\
\text { advanced design researches }\end{array}$ & $\begin{array}{l}7 \text { Classes/ } \\
21 \text { credits }\end{array}$ & $\begin{array}{l}16 \text { Credits } \\
3 \text { Credits }\end{array}$ & $\begin{array}{l}\checkmark \\
\checkmark\end{array}$ & $\checkmark$ & $\begin{array}{l}\text { Minimum } 2 \\
\text { credits }\end{array}$ & $\checkmark$ & $\checkmark$ \\
\hline METU & $\begin{array}{l}\text { Focuses on research and } \\
\text { development in institutional } \\
\text { context and in an } \\
\text { interdisciplinary field. Offers } \\
\text { specialization on usability } \\
\text { and human factors as well } \\
\text { as interaction design }\end{array}$ & $\begin{array}{l}7 \text { Classes/ } \\
21 \text { credits }\end{array}$ & $\begin{array}{l}3 \text { Credits } \\
6 \text { Credits }\end{array}$ & $\begin{array}{l}\checkmark \\
\checkmark\end{array}$ & $\checkmark$ & 12 Credits & $\checkmark$ & $\checkmark$ \\
\hline$A U$ & $\begin{array}{l}\text { Offers technical and } \\
\text { theoretical education on } \\
\text { application and industry } \\
\text { based on presentation with } \\
\text { computer support }\end{array}$ & $\begin{array}{l}7 \text { Classes/ } \\
21 \text { credits }\end{array}$ & $\begin{array}{l}9 \text { Credits } \\
3 \text { Credits }\end{array}$ & $\begin{array}{l}\checkmark \\
\checkmark\end{array}$ & $\checkmark$ & 9 Credits & $\checkmark$ & $\checkmark$ \\
\hline IEU & $\begin{array}{l}\text { Offers institutional and } \\
\text { application oriented } \\
\text { education that cares for } \\
\text { research presentation } \\
\text { techniques with an } \\
\text { interdisciplinary perspective }\end{array}$ & $\begin{array}{l}9 \text { Classes/ } \\
27 \text { credits }\end{array}$ & 18 Credits & $\checkmark$ & & 9 Credits & $\checkmark$ & $\checkmark$ \\
\hline
\end{tabular}

Notes: $\mathrm{T}=$ theory; $\mathrm{P}=$ practice. 


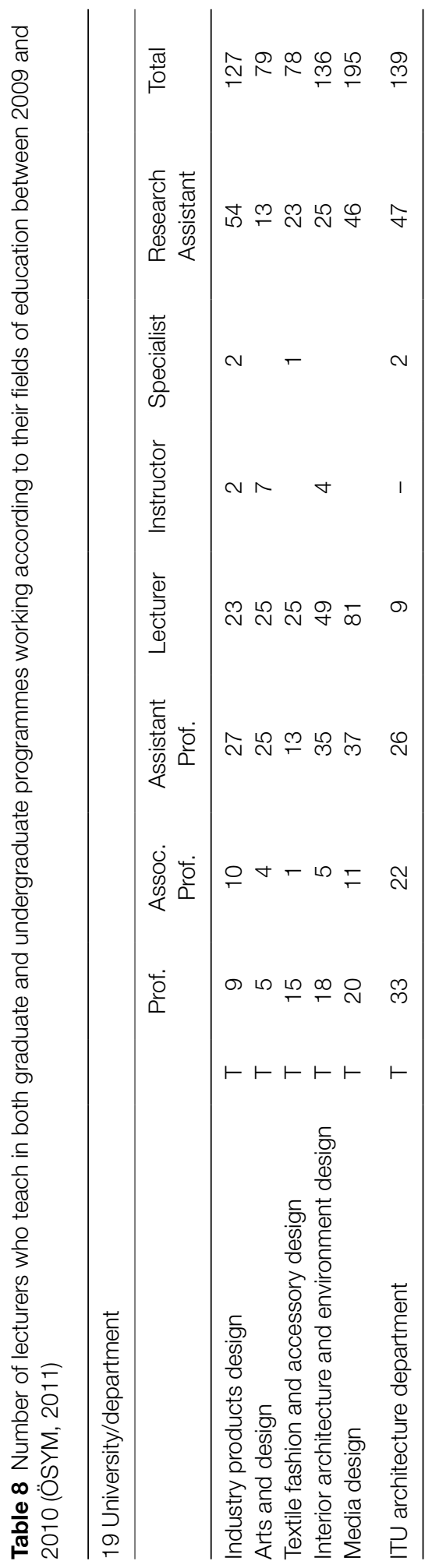






Figure 4

Percentage distributions of obligatory courses in undergraduate education at IPD and ID departments.

percentages are quite different. We can see that almost all of these universities attach importance to those courses that are critical in forming the identity of a designer.

Upon examination of Figure 5, it can be seen that the syllabuses of departments offering IPD and ID education are composed mostly of obligatory courses, and elective courses seem to occur at a far below-average rate. Within the framework of accreditation in higher education, which has been raised in proportion to the free roaming of professionals within EU states referred to as the Bologna process, the level of elective courses must be at least 25 per cent. We can see that the IPD and ID syllabuses of many universities fail to meet such a condition.

\section{Design Profession and Recruitment}

\section{Qualifications sought by industry in IPD and \\ ID graduates}

In this section, the qualifications sought by industry in IPD and ID graduates are evaluated in comparison with findings contained in another, empirical study (Erkarslan et al, 2011). In that study, the current syllabuses of IPD and ID departments that belong to art and design faculties, fine arts faculties, architecture faculties and industrial arts academies of ten universities in Turkey were examined and the job advertisements published in the last four months of 2009 via seven Web portals in Turkey were scanned and examined. From 


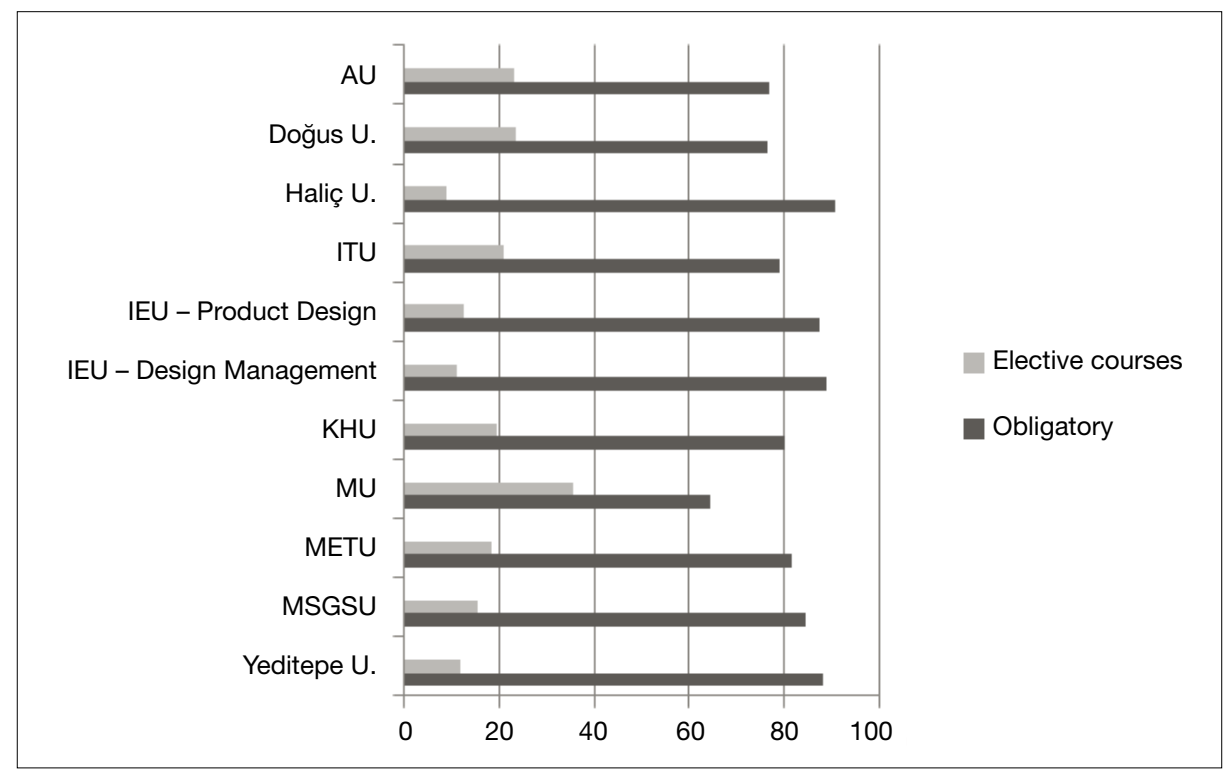

Figure 5

Distribution percentages of obligatory and elective courses that must be taken in IPD and ID undergraduate education.

this data, the profile of the industrial designer from industry's point of view was revealed.

In this study, however, we have not included a detailed syllabus analysis of IPD and ID departments. The findings related to the expectations of industry contained in this study are the original findings of the empirical study; these have been summarized to give a broad idea of the expectations of industry, not for purposes of generalization. In addition, the data contained in this study do not contain detailed analyses of the syllabuses; it focuses only on a general review of the qualifications contained in the job advertisements.

The qualifications that employers look for in an industrial designer include design skills (the ability to develop design solutions, access to information, R\&D and the possession of qualifications that could help these to be developed in two and three dimensions, including computer-aided design and production, drawing, sketch techniques and the development of creative problem solution techniques), contextual understanding (history of design, design theory, marketing) and design knowledge (material information, production method, modelling) (Figure 6).

When comparing Figure 4 with Figure 6, we can see that university programmes reveal the closest distribution of the qualifications sought by the employers. While 85.2 per cent of employers absolutely required the 'design knowledge' qualification, 44.4 per cent and 51.8 per cent attach importance to the 'design skills' and 'contextual understanding' qualifications, respectively. Each student 


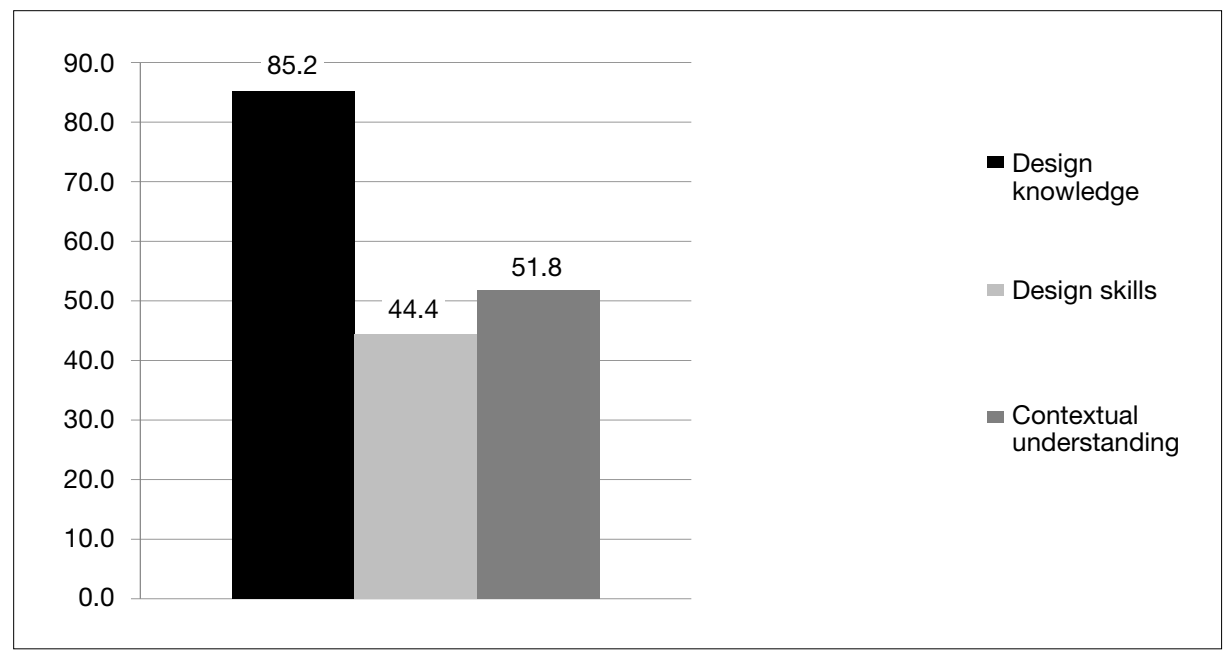

\section{Figure 6}

Percentages of qualifications sought in ID job advertisements according to course categories (Erkarslan et al, 2011).

educated by the ten universities possesses all these qualifications, though at varying degrees. It is astonishing that the percentage of the requirement for those qualifications acquired through the 'design skills' course remains at only 44.4 per cent in job advertisements. This result suggests that a majority of employers cannot utilize the qualifications possessed by the employee efficiently.

\section{Findings of the Study}

As a result of the analysis of the job listings, we determined that 72 per cent of the qualifications employers are looking for are professional qualities whereas 28 per cent of the qualifications are identified as additional qualities such as experience, teamwork and foreign languages. On the basis of these findings, it is possible to say that industry employers place greater importance on professional qualities in their employment decisions.

When professional qualities sought by employers are analysed, the results show that design skills are the most important, at 57 per cent, contextual understanding comes in second, at 22.1 per cent and design knowledge is third, at 20.9 per cent, as shown in Figure 7 . When the curricula of the programmes are analysed, we find that elective courses cover only 18.25 per cent of the overall courses. While the contribution of the elective courses in the graduate profile is limited, compulsory courses play a significant role in this process.

When all of the compulsory courses are examined, we can determine that the design knowledge category is generally represented in the curricula in different ratios ranging from 22 to 64 per cent; 


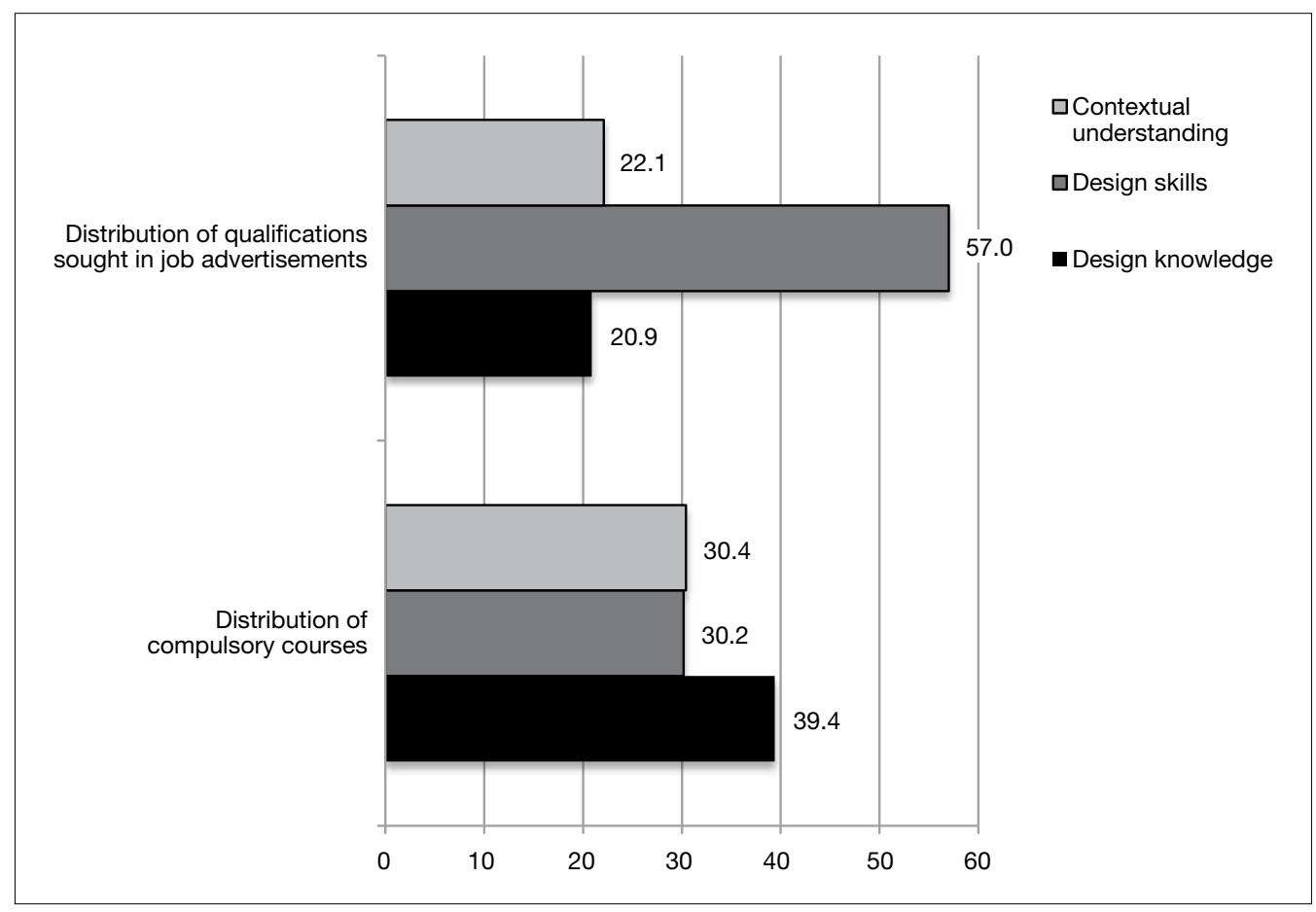

Figure 7

Comparison of job advertisements and compulsory courses in IPD and ID departments (Erkarslan et al, 2011).

however, the emphasis placed on design knowledge in industry is only 20.9 per cent. Courses in the design skill category are represented in the curricula in ratios that range between 19 and 39 per cent, while the expectation of industry ranks design skills at 57 per cent. Courses in contextual understanding are represented in the curricula in ratios ranging from 12 to 47 per cent while the expectation of the industry ranks the importance of contextual understanding at 22.1 per cent.

These results strongly suggest that the expectations of industry and the educational emphasis of university programmes are extremely incompatible. When elective courses are analysed, the courses in the design knowledge category are represented in the curricula in ratios between 0 and 37.4 per cent, courses in the category of design skill are represented in the curricula in ratios between 31 and 55.2 per cent and courses in the category of contextual understanding category are represented in ratios between 17.2 and 56 per cent. The number of elective courses offered in design skills is remarkable, and it can be proposed that this emphasis helps to compensate for the identified weakness in this category found in the compulsory courses (Erkarslan et al, 2011). 


\section{Conclusions}

According to findings derived from this study, Turkey is behind other countries in terms of intellectual rights, patenting, new products, and the development and investment in new fields of business. The share of resources allocated for R\&D is scarce, and the incentives pertaining to sustainable design concept are not adequate. Unemployment rates are high, and industrial designers have a difficult time finding jobs in industry. Statistical data related to design education and industry are incomplete and far from reliable. Data from the Student Selection and Placement Centre (ÖSYM, 2011) and other reports indicate that media design (communication, digital and multimedia), interior architecture and environment design have gained in popularity, and such popularity growth is in line with the growing media industry.

The interdisciplinary characteristic of IPD and ID graduate programmes enable information and skills pertaining to different fields to be employed, increase the quality of education in the cultivation of innovativeness and creativity and elevate student profiles positively. IPD and ID departments that are connected to databases, digital libraries and communication networks have gained new experiences due to joint programmes and exchanges of student, lecturer and administrative personnel with foreign IPD departments abroad.

Despite these steps, the cooperation between university and industry remains at an undesired level. The renewal frequency of syllabuses is below the expectations of industry. IPD and ID graduate programmes remain far from the specialization-based education model and there is a serious shortage of permanent lecturers in these departments. As a result of evaluations, IPD and ID departments have been attaching importance to courses that focus on design skills. Moreover, it can be observed that obligatory courses comprise the majority of courses in syllabuses and elective courses that are supposed to be taken remain relatively low in number and frequency.

Our findings indicate that, for industrial designer employment, employers give priority to design skills, contextual understanding and design knowledge. It has been shown that university education programmes where courses that aim to teach 'design skills' comprise the majority seem to reflect most closely the distribution of the qualifications sought by employers of industrial designers. Moreover, our study has shown that, in the employment of designers, most employers fail to effectively benefit from the qualifications possessed by the industrial designer.

\section{References}

Ball, L. (2002). 'Preparing graduates in art and design to meet the challenges of working in the creative industries: a new model for work'. Art, Design and Communication in Higher Education, 1(1), 10-24. 
Bonsiepe, G. (1991). Developing Countries: Awareness of Design and the Peripheral Condition, History of Industrial Design 19191990: The Dominion of Design. Milan: Electa.

Boyarski, D. (1998). 'Education: Designing design education'. Special Interest Group on Computer and Human Interaction Bulletin, 30(3): 2.

Çırpanlı, T. and Er, H. A. (2006). 'Tasarımı KOBi'lerle Buluşturmak: Türkiye ve İtalya'dan İki Üniversite Sanayi İşbirliği Projesi' ('Making design met with SME's: Two examples for university-industry collaboration projects in Turkey and Italy'). In Er, H. A., Timur, Ş., Ece Arıburun, L. N., Hümanur Bağlı, H., Oğulcan İlhan, A., Zeki Turan, A., Turan, G., Küçükksayraç, E. and Ensici, A. (eds), III. Ulusal Tasarım Kongresi: Türkiye'de Tasarımı Tartışmak Bildiri Kitabı. Istanbul: The Istanbul Technical University Press, pp. 42-59.

Cooper, R. and Press, M. (1995). The Design Agenda: A Guide to Successful Design Management. Chichester: John Wiley \& Sons.

Elçi, Sirin (2010). 'Turkey'. UNESCO Science Report-2010 [online]. Available at: http://unesdoc.unesco.org/images/0018/ 001899/189958E.pdf [accessed 9 January 2011].

Er, H. A. (1993). 'The state of design: Towards an assessment of the development of industrial design in Turkey'. METU Journal of Faculty of Architecture, 13(1-2): 3151.

Er, H. A., Korkut, F. and Er, O. (2003). 'US involvement in the development of design in the periphery: The case history of industrial design education in Turkey 1950s-1970s'. Design Issues, 19(2): 17-35.

Erkarslan, O. (1998). 'Tasarımda Doktora Eğitimi Üzerine Alternatif Öneriler' ('Suggestions for PhD education in design'. In Er H. A. and Er, Ö. (eds) Endüstriyel Tasarım Eğitimi: ITÜ Endüstriyel Tasarım Toplantıları 1998-1999 (Proceedings on Industrial Design Education 1998-1999 ITÜ). Bildirileri ITÜ Endüstri Ürünleri Tasarımı Bölümü, Nisan 2004. Istanbul: Istanbul Technical University Press.

Erkarslan, O. (2007). 'Inter-disciplinary characteristic of design profession: Bridging the gap between design education and industry'. Designtrain Congress Trailer I, Amsterdam, The Netherlands, 10-12 May 2007, pp. 213-218.

Erkarslan, O and Imamogulları, B. (2010). 'Comparative analysis of master of industrial design education in Turkey', Design and Technology Education: An International Journal, (15)3: 41-57.

Erkarslan, O., Kaya, A. and Dilek, O. (2011). 'Comparative analysis of recruitment qualifications of industrial designers in Turkey through undergraduate education programmes and online recruitment resources'. International Journal of Technology and Design Education, 2011. Available at: http://link.springer.com/ article/10.1007/s10798-011-9164-6/fulltext.html [accessed 12 January 2011]. 
Evyapan, N., Korkut, F. and Hasdoğan, G. (2005). Implications of Collaboration with Industry for Educational Strategies in Industrial Design: The Graduation Project Course. Ankara: METU, Faculty of Architecture Press, pp. 137-159.

Kaufmann, J. (1998). 'Why design education? Infrastructure issues affecting the future of industrial design education'. The 1998 IDSA National Education Conference (CD ROM).

Kiper, M. (2010). ‘Dünyada ve Türkiye'de Üniversite-Sanayi İşbirliği ve Bu Kapsamda Üniversite-Sanayi Ortak Araştırma Merkezleri Programı (ÜSAMP)'. Available at: http://www.ttgv.org.tr/content/ docs/usi_kitap.pdf [accessed 20 April 2011].

Kolko, J. (2004). 'New techniques in industrial design education' [online]. The 6th International Conference of the European Academy of Design Proceedings. Available at: www.jonkolko. com/projectFiles/writing/ead06_id115_2.pdf [accessed 26 March 2007].

Süel, A. B. (2006). 'Türk Endüstrisinde Firma İçi Çalışan Endüstriyel Tasarımcının Rolü: Üreticilerin ve Tasarımcıların Algıları’. Orta Doğu Teknik Üniversitesi, Fen Bilimleri Enstitüsü, Endüstri Ürünleri Tasarımı Anabilim Dalı, Yayımlanmamış Yüksek Lisans Tezi. Unpublished master's thesis, Ankara.

Wang, K. (2008). 'Research of the recruiting qualifications of the ID profession and their implication in ID education: Computeraided industrial design and conceptual design', CAID/CD 2008, Kunming, China, pp. 851-854.

Yang, M. Y., You, M. and Chen, F. C. (2005). 'Competencies and qualifications for industrial design jobs. Implications for design practice, education, and student career guidance'. Design Studies, 26(2): 155-89.

Yeh, W. D. (2003). 'The demand and the evaluation of industrial design profession from the industries'. The 6th Asian Design Conference (CD ROM).

\section{Internet Sources}

Capital (2007). Available at: http://www.capital500.net/capital/ca07. htm [accessed 16 April 2011].

Design Council (2007). Available at: http://www.designcouncil.org. uk/publications/highlevel-skillsforhighervalue/ [accessed 16 April 2011].

Design Council (2010). Available at: http://www.designcouncil. org.uk/ourwork/insight/research/designindustry-research2010/ [accessed 9 November 2010].

ETMK (2010). Available at: http://www.etmk.org.tr/about/ membership/list [accessed 16 October 2010].

GMK (2011). Available at: http:www.gmk.org.tr/eng_goster.php ?neyi Goster=eng_ uyeListesi [accessed 16 October 2010]. 
iSKUR (2011). Available at: http://www.ecorys.com.tr/projects/110_ iskur-turkish-employment-agency-active-labour-marketmeasures-project-ii [accessed 12 April 2011].

Official Gazette (2009). Available at: http://www.resmi-gazete.org/ tarih/20090903 10.htm [accessed 12 April 2011].

ÖSYM (2010). Available at: http://osym.gov.tr/belge/1-12270/2010ogrenci-secme ve-yerlestirme-sistemiadaylarin-yuk-.html [accessed 12 April 2011].

ÖSYM (2011). Available at: http://www.osym.gov.tr/belge/112038/2009-2010-ogretim-yili yuksekogretim-istatistiklerikit-. html [accessed 12 April 2011].

ÖSYM (2012). Available at: http://www.osym.gov.tr/belge/112038/2009-2010-ogretim-yili yuksekogretim-istatistiklerikit-. html [accessed 14 April 2012].

PriceWaterhouseCoopers (2010). Available at: http://www.pwc. $\mathrm{com} / \mathrm{tr} / \mathrm{tr} /$ press releases/2010/Kuresel- Eglence ve-Medyaya Bakis-2010-2014-Raporu.jhtml [accessed 28 April 2011].

TiM (2011). Available at: http://www.tim.org.tr/tr/ihracat-ihracatrakamlari tablolar.html [accessed 12 April 2011].

TPE (2010). Available at: http://www.tpe.gov.tr/portal/default_ en.jsp?sayfa $=144$ [accessed 27 December 2010].

TÜiK (2010). Available at: http://www.tuik.gov.tr/VeriBilgi.do?alt_ id=25 [accessed 27 December 2010].

TÜBITAK (2003). Available at: http://www.tubitak.gov.tr/home. do ? sid $=0 \& q=\% 20$ USAMP $\% 20$ ortak $\% 20$ ara $\%$ C $5 \%$ 9Ft\%C4\%B1rma\%20projes,\%20\&cid=27271 [accessed 27 December 2010].

TYDTA (2010). Available at: http:www.invest.gov.tr/enUS/turkey/ factsandfigures/Pages/Economy.aspx [accessed 27 December 2010].

ÜSAMP (2003). Available at: http://www.inovasyon.org/html/usamp. htm [accessed 27 April 2011].

WIPO (2010). WIPO Publication No. 941(E).http://www.wipo.int [accessed 29 December 2010].

World Bank (2009). Turkey National Innovation and Technology System Europe and Central Asia Region Recent Progress and Ongoing Challenges. Available at: http://ekutup.dpt.gov. tr/tg/http://wwwwds. worldbank.org/external/default/WDSCon entServer/WDSP/IB/2009/10/23000333038_20091023010710/ Rendered/PDF/48 550ESWOTROP101OfficialOUse0Only1pd (Report No. 48755-TR) [accessed 4 January 2011].

World Bank (2010). 'Country brief 2010'. Available at: http:// go.worldbank.org/VQSCYP1Y50 [accessed 4 January 2011].

YÖK (2011). Available at: http://www.osym.gov.tr/belge/112038/2009-2010-ogretim yiliyuksekogretimistatistikleri-kit-.html [accessed 7 January 2011]. 


\section{University Web Pages}

Anadolu University (AU) (2008). Available at: http://www.anadolu. edu.tr/en/ [accessed 15 June 2008].

Doğuş University (DU) (2011). Available at: http://www.dogus.edu.tr [accessed 20 April 2011].

Haliç University (HU) (2011). Available at: http://www.halic.edu.tr [accessed 20 April 2011)

Istanbul Technical University (ITU) (2008). Available at: http://www. itu.edu.tr/en [accessed 15 June 2008].

Izmir Institute of Technology (IZTECH) (2008). Available at: http:// www.iyte.edu.tr [accessed 15 June 2008].

Izmir University of Economics (IEU) (2008). Available at: http://www. iue.edu.tr [accessed 15 June 2008].

Kadir Has University (KHU) (2011). Available at: http://www.khas. edu.tr/ [accessed 20 April 2011].

Marmara University (MU) (2008). Available at: http://www.marmara. edu.tr/en [accessed 15 June 2008].

Middle East Technical University (METU) (2008). Available at: http:// www.metu.edu.tr [accessed 15 June 2008].

Mimar Sinan Fine Arts University (MSGSU) (2008). Available at: http://www.msgsu.edu.tr [accessed 15 June 2008].

Yeditepe University (YU) (2008). Available from: http://www.yeditepe. edu.tr/ [accessed 15 June 2008].

\section{Abbreviations}

ETMK, Industrial Designers' Occupational Organization.

EU, European Union.

GMK, Turkish Graphic Designers' Occupational Organization.

GNP, Gross National Product.

ID, Industrial design.

IPD, Industrial product design.

iSKUR, Turkish Employment Agency.

OECD, Organization for Economic Cooperation and Development.

ÖSYM, Student Selection and Placement Center.

R\&D, Research and Development.

SMEs, Small- and Medium-scaled Enterprises.

TÜiK, Turkish Statistical Institute.

TiM, Turkish Exporters' Assembly.

TPE, Turkish Patent Institute.

TTDK, Turkish Design Advisory Council.

TÜBITAK, Turkish Institute of Scientific and Technological Research.

TYDTA, Turkish Investment Support and Promotion Agency.

UNSD, United Nations Statistics Department.

ÜSAMP, University-Industry Joint Research Centres Program.

WIPO, World Intellectual Property Organization.

YÖK, Higher Education Council. 


\section{Biography}

Onder Erkarslan is a Professor and Chair of the Department of Industrial Design in the Izmir Institute of Technology, Urla Campus, Izmir, Turkey. His research interests focus on qualitative research methods in design, curriculum studies and industrial design education. Dr Erkarslan has also published numerous articles in scientific journals and given numerous presentations at conferences. He is currently working as the director for the project entitled 'A study of classroom furniture dimensions and anthropometrics in adolescent students in Izmir', which is supported by IZTECH-SRPF (Izmir Institute of Technology-Scientific Research Project Fund 2010IYTE31).

\section{Address for Correspondence}

Prof. Dr Onder Erkarslan, Department of Industrial Design, Izmir Institute of Technology, Gulbahce Campus, 35430 Urla, Izmir, Turkey. Tel: +90 (232) 7507065

Email: ondererkarslan@iyte.edu.tr 